\title{
Google, Novartis back Medicxi's ambitions
}

Venture capital firm Medicxi had little trouble raising its latest, \$300-million fund, devoted to European biotechs with at least one phase 2 asset. The oversubscribed fund is backed by Novartis, the European Investment Fund, and Verily Life Sciences, a division of Google's parent company Alphabet.

Medicxi designed its Growth I fund to help European biotechs mature into commercialstage companies. Traditionally, as they reach proof of concept, European biotechs partner with big pharma for their deep pockets and late-stage clinical development expertise. But for some companies, "it's not right to transact with pharma early. Some should stay independent longer," asserts Francesco De Rubertis, cofounder and partner at London-based Medicxi, spun out of Index Ventures in 2016 to focus on life sciences. Medicxi's new fund will support biotechs whose assets, and management teams, give them the potential to become sustainable, commercial-stage biotechs-like Allschwil, Switzerland-based Actelion, which remained independent for many years before being acquired by Johnson \& Johnson early in 2017 (Nat. Biotechnol. 35, 183-184, 2017).

The funding gap in Europe isn't new. Europe has long lacked the long-term capital to nurture

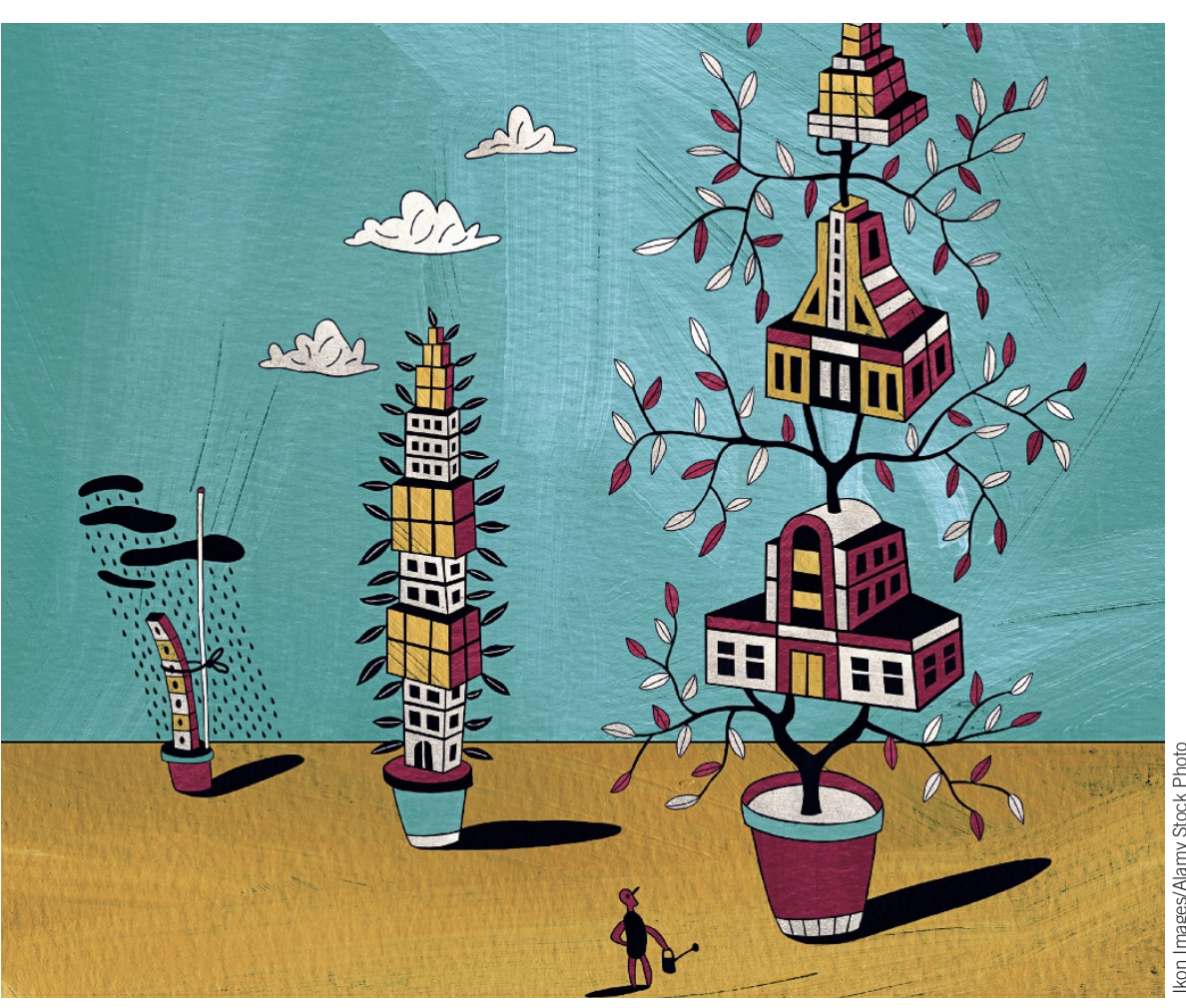

Medicxi's growth fund will help entrepreneurs build companies beyond clinical proof-of-concept stage. the next Genentech or Gilead. In 2008, Index Ventures launched a late-stage fund, Index Ventures Growth I, for both tech and biotech. But it rapidly became very tech-focused. This wasn't just because of the faster pace of technology investing; it was also because Europe's relatively young biotech sector didn't then have the experienced biotech management teams it now has to ensure the startups flourished. That is part of the reason for Medicxi's asset-centric approach for its early-stage funds: company infrastructure is kept to a minimum and the venture capital partners are very hands-on. Today, however, "we have the assets, and we have management teams, inspired by [Copenhagen-based] Genmab or Actelion, with the ambition to become late-stage companies," says De Rubertis. "So cash has become the bottleneck." Medicxi Growth I expects to lead syndicates and invest $€ 10-25$ million (\$11.4-28.6 million) per company.

The late-stage fund will continue to be asset-centric, even though it will be investing in entire companies and their management teams, mostly (but not exclusively) in Europe. "We'll be driven... by a specific molecule that we believe will become an important drug," says De Rubertis. It won't be a contractual agreement with the management, but an aligned vision, he explains. And that's fine, since "we know most of the management teams in Europe," he says.

That European network helps explain Verily's involvement. The Google family has long shown its interest in healthcare; sister company GV (formerly Google Ventures), based in Mountain View, California, has accelerated its investments in biopharma with 17 deals in the last three years, according to $C B$ Insights_including a handful in Europe, such as Dublin-based Carrick Therapeutics. Verily itself has so far stuck mostly to health technologies and devices, such as its glucosesensing contact lens project with Novartis. This investment is "an exploration into Europe for them," says De Rubertis. It's an efficient one: with this single investment, Verily enters European biotech networks and gets to meetand back-some of the region's most promising entrepreneurs. (Verily contacted Medicxi, late in the fund's gestation, for a piece of the action.) Both Verily and Novartis will have two seats on the fund's scientific advisory board, though neither will have preferential rights to buy or deal with portfolio companies.

Medicxi Growth I has already invested in Geneva-based ObsEva SA, whose two lead assets have just entered phase 3. Nolasiban is an oral oxytocin receptor antagonist that may increase the chances of successfully implanting embryos into women receiving in vitro fertilization treatment. OBE2109 is a novel oral gonadotropin-releasing hormone receptor antagonist in development for uterine fibroids.

Joe Anderson, CEO of London-based Arix Bioscience, welcomes the new fund. "There's a dearth of capital in European biotech," he agrees. But the need isn't limited to late-stage groups. Medicxi has separate funds supporting both startups and established firms, but can't use its growth fund to finance companies maturing from its early-stage fund. Arix, publicly listed since early 2017, says it can provide long-term capital, freed from the exit pressure of a fund structure.

Medicxi Growth I will exit its investments "when the phase $2 / 3$ asset becomes a good medicine that's approved and selling," notes De Rubertis, estimating a four- to six-year time-frame. Yet "it's not a time-based [investment] strategy," he insists. Some companies may well be acquired once they reach phase 3 , but that outcome "is not a condition for our investment."

Melanie Senior London 